\title{
The Effect of Net Profit Margin, Debt to Equity Ratio, and Return on Equity against Company Value in Food and Beverage Manufacturing Sub-sector Companies listed on the Indonesia Stock Exchange
}

\author{
Janice $^{\mathbf{1}}$, Nagian Toni ${ }^{2}$ \\ ${ }^{1}$ Master Student in Universitas Prima Indonesia \\ ${ }^{2}$ Lecturee in Universitas Prima Indonesia
}

\begin{abstract}
This research deals with the effect of net profit margin, debt to equity ratio, and return on equity against company value in food and beverage manufacturing sub-sector companies listed on the Indonesia stock exchange. The variables in this study are described using descriptive statistics. The result shows that Partially, Net Profit Margin has no effect on the company value in food and beverage companies on the Indonesia Stock Exchange in 2014-2018. Partially, Debt to Equity has no effect on the company value in food and beverage companies on the Indonesia Stock Exchange in 2014-2018. Partially, Return on Equity affects the company value in food and beverage companies on the Indonesia Stock Exchange in 2014-2018.
\end{abstract}

Keywords

Net profit margin; debt to equity ratio, return on equity, company

value

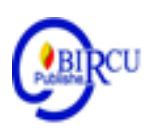

\section{Introduction}

High and low stock prices of a company can be observed and studied with two approaches both technically and fundamentally. Technically, observations are carried out by paying attention to the charts in a coherent manner from several observations (time series) to get a picture of stock movements, but on the other hand technical analysis can also be used such as studying and observing based on the company's financial performance, demand and supply, interest rates, risk levels, inflation rates, government policies, political conditions and security of a country. However, the company's financial condition has the most dominant influence on the formation of stock prices.

The company's financial report that are often used in analysis are the balance sheet and income statement. The balance sheet shows all the assets owned by a company at a point in time and the source of capital to buy these assets. Periodically public companies listed on the exchange must publish their financial statements, while the income statement provides an overview of the company's performance. Simply put, stock prices can be predicted by analyzing available financial data.

Some of the methods used to measure company value are Price Earning Ratio (PER) showing how much money investors are willing to spend to pay every dollar of reported profit (Brigham and Houston, 2006: 110). This ratio is used to measure how much the ratio between the company's stock prices with the profits obtained by shareholders. The use of price earning ratio is to see how the market appreciates the company's performance which is reflected by its earnings per share. Price earning ratio shows the relationship between the ordinary stock market with earnings per share. Price earning ratio (PER) serves to measure 
changes in profitability that is expected in the future. The greater the PER, the greater the possibility of the company to grow so as to increase the company value. Price to Book Value (PBV) is a ratio that shows whether the stock price traded is overvalued (above) or undervalued (below) the book value of the stock (Fakhruddin and Hadianto, 2001), Price to Book Value (PBV) illustrates how large the market appreciate the book value of a company's stock. The higher this ratio, the market believes the company's prospects. PBV also shows how far a company is able to create company value relative to the amount of capital invested.

If the PER ratio focuses on the company's net profit, the PBV ratio looks more at the company's equity value. Therefore, PBV can be defined as a ratio comparing the stock's market value to the book value per share (the value of shares when shares are first sold to investors). The greater the PBV ratio the higher the company is valued by investors relative to the funds that have been invested in the company.

Another alternative used in measuring company value is to use the Tobin's Q method developed by James Tobin. Tobin's Q is calculated by comparing the ratio of the market value of a company's stock with the book company value's equity (Weston and Copeland, 2001).

\section{Review of Literature}

\subsection{Net Profit Margin}

Often we face problems when we want to invest, where we have to choose companies that are more attractive than attractive. Very difficult to determine, of course, because everything is interesting. If we have a lot of money, we can just buy everything. But if our money is limited, it becomes a problem. As a solution, we must choose one of them.

Attractive companies are those who enjoy high profit margins and generate cash profits for their owners. This attraction continues if the company's net profit gives a high return on the company's equity. Profit Margin or Net Profit Margin is a comparison of the total amount of net profit with the total amount of company income. This term is also known by its abbreviation, NPM. NPM is usually used to measure a little or a lot of company profits.

For Investors, this Net Profit Margin is usually used to measure how efficiently the management manages the company and also estimates future profitability based on sales forecasts made by management. By comparing net income with total sales, investors can see what percentage of income is used to pay operating costs and non-operating costs and what percentage of the remaining can pay dividends to shareholders or reinvest in the company Net profit margin is calculated using the following formula:

$$
\text { NetProfitMargin }=\frac{\text { Net } \text { Profit }}{\text { Net Sales }}
$$

\subsection{Debt to Equity Ratio Theory}

Debt to Equity Ratio or in Indonesian language is a financial ratio that shows the relative proportion between Equity and Debt used to finance company assets. This Debt to Equity Ratio is also known as the Leverage Ratio, which is the ratio used to measure how well the investment structure of a company.

Debt to Equity Ratio or DER is the main financial ratio and is used to assess a company's financial position. This ratio is also a measure of a company's ability to pay off obligations. This Debt to Equity Ratio is an important ratio to consider when examining the financial health of a company. If the ratio increases, this means that the company is financed by creditors and not from its own financial sources which may be a fairly dangerous trend. 
Lenders and investors usually choose a low Debt to Equity Ratio because their interests are better protected if there is a decline in business at the company concerned. Therefore, a company that has a high Debt to Equity Ratio may not be able to attract additional capital with loans from other parties.

The formula for calculating Debt to Equity Ratio is:

$$
\boldsymbol{D E R}=\frac{\text { Total Hutang }}{\text { Total Equity }}
$$

\subsection{Return on Equity Theory}

ROE (Return on Equity) compares net income after tax with equity that has been invested by shareholders of the company (Van Horne and Wachowicz, 2005: 225). This ratio shows the power to generate a return on investment based on the book value of shareholders, and is often used in comparing two or more companies for good investment opportunities and cost effective management. ROE is very attractive to holders and prospective shareholders, and also to management, because the ratio is an important measure or indicator of shareholders value creation, meaning that the higher the ROE ratio, the higher the company value, this is certainly an attraction for

$$
\text { Return on Equity }=\frac{\text { Laba Setelah Tax }}{\text { Total Equity }}
$$

Based on what has been described previously, the conceptual framework in this study can be described as follows:

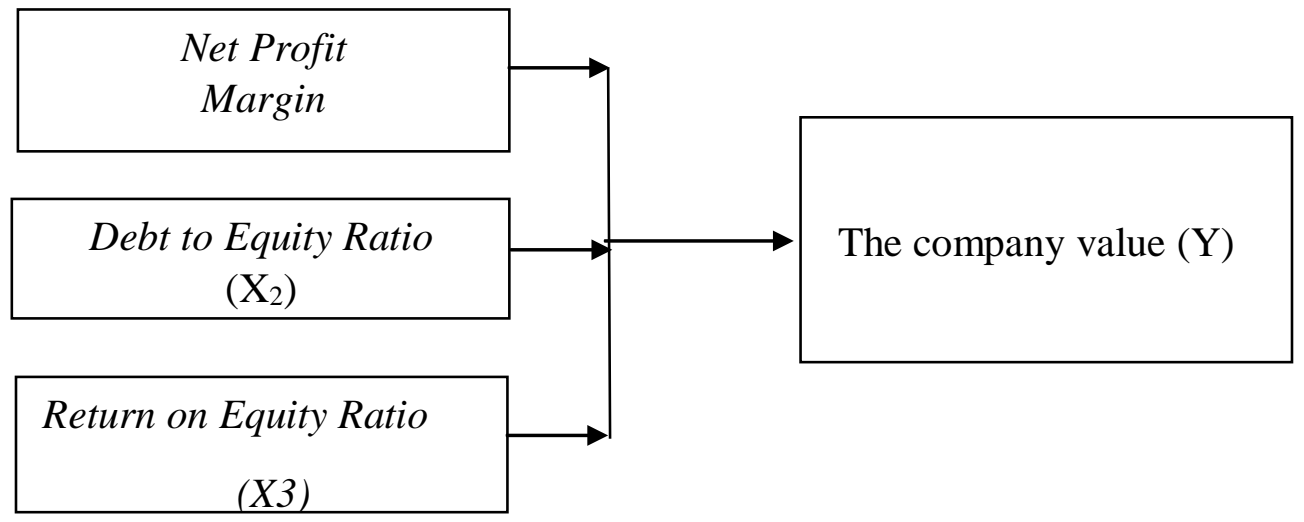

Figure 1. Conceptual Framework

\section{Research Method}

This research was conducted at Food and Beverage sub-sector manufacturing companies listed on the Stock Exchange in 2014-2018 period with the address of the Stock Exchange office on Jalan Jenderal Sudirman Kav. 52 - 53 Jakarta, Indonesia:

\subsection{Independent Variable}

a. Net Profit Margin (X1), which is the profitability ratio used to measure the percentage of net income in a company against net sales. This Net Profit Margin shows the proportion of sales remaining after deducting all related costs. The proxies used for NPM are as follows: 
Net Profit Margin $=\frac{\text { Net Profit }}{\text { Net Sales }}$

b. Debt to Equity Ratio / DER (X2) is the ratio of the ability of food and beverage manufacturing companies to cover loans from their own capital. The proxy used for this DER is as follows:

$$
\text { DER }=\frac{\text { Total Hutang }}{\text { Total Equity }}
$$

c. Return on Equity Ratio (X3) is the ratio of the ability of food and beverage manufacturing companies to generate profits using their own capital. The proxies used for ROE are as follows:

$$
\text { Return on Equity }=\frac{\text { Laba Setelah Tax }}{\text { Total Equity }}
$$

\subsection{Dependent Variable}

The dependent variable in this study is company value. The tool used in measuring the value of this company is Price to Book Value (Y). The price used in this case is the closing price divided by the Book Value of Shares (total equity divided by total outstanding shares). Calculation of the company value / calculation of this Price to Book Value is to find out how expensive or cheap the stock price of a company is today. Price to Book Value also consistently and precisely represents the fair company value's stock value. Because Price to Book Value is calculated based on company equity where as long as the company is able to generate profits, its value will also continue to rise.

\subsection{Classical Assumption Tests}

The classic assumption test is a statistical requirement that must be met in multiple linear regression analysis. Before testing the hypothesis, first testing is done whether there is a violation of classical assumptions. The results of testing a good hypothesis is testing that does not violate. These tests include: normality test, multicollinearity test, autocorrelation test, and heteroscedasticity test.

\section{a. Normality Test}

The normality test aims to test whether in the regression model, the dependent variable and the independent variable both have normal or abnormal distributions. A good regression model is to have normal or near-normal data distribution. The normality test is carried out with the SPSS 24.0 program which uses the One-Sample KolmogorovSmirnov Test and the Normal Propability Plot. In the Normal Propability Plot, data normality can be detected by looking at the spread of data (points) on the diagonal axis of the graph. The basis of decision making is if the data spreads around the diagonal line and follows the direction of the diagonal line, then the regression meets the assumption of normality. If the data spreads far from the diagonal line and or does not follow the direction of the diagonal line, the regression model does not meet the assumption of normality.

In the One-Sample Kolmogorov-Smirnov Test, the criteria are:

1) If Asymp. Sig. (2-tailed) $<0.05$, the regression model does not produce residual values with normal distribution or reject $\mathrm{H} 0$. 
2) If Asymp. Sig. (2-tailed) $\geq 0.05$, the regression model produces a normal distribution of values or accept $\mathrm{H} 0$.

\section{b. Multicollinearity Test}

The purpose of multicollinearity testing is to test whether the regression model found a correlation between independent variables. If there is, it means there is multicolinearity. A good regression model should not have a correlation between independent variables (Santoso, 2001). Testing whether there is multi-colinearity can be detected by looking at the amount of VIF (Variance Inflation Factor) and tolerance value. The allowable VIF value limit is a maximum of 10 . VIF values greater than 10 indicate high colinearity. Guidelines for a regression model that does not have multicollinearity are:

VIF $<=10$

1) Tolerance value $>0.1$ where tolerance $=1 / \mathrm{VIF}$ or VIF $=1 /$ tolerance

\section{c. Autocorrelation Test}

The autocorrelation test is a statistical analysis conducted to find out whether there is a correlation of variables that exist in a prediction model with a change in time. If the data is in a series of time series, autocorrelation test needs to be done. This test is important because a value in a particular observer sample is strongly influenced by the value of previous observations, whether in the linear regression model there is a correlation between the error of the intruder in period $t$ and the error of the intruder in period t-1 (previous). In this study autocorrelation testing was performed using the Durbin-Watson method. In this case there are 2 values, namely du (durbin upper) and dl (durbin lower). If the value of durbin watson (d) is between du and $4 \mathrm{du}$, then there is no autocorrelation, and vice versa.

Requirements for autocorrelation among others:

1) If $0<\mathrm{d}<\mathrm{dl}$ then there is no positive autocorrelation so the decision is rejected

2) If $\mathrm{dl} \leq \mathrm{d} \leq \mathrm{du}$ then there is no positive autocorrelation so there is no decision

3) If 4 -dl $<d<4$ then there is no negative correlation so the decision is rejected.

4) If $4-d u \leq d \leq 4$ - $d$ l then there is no negative correlation so there is no decision.

5) If $d u<d<4-d u$ then there is no positive or negative autocorrelation so the decision is not rejected.

If the test using the Durbin Watson method is not successful, then it is carried out with a Run Test from the SPSS program, where if the Asymp value. Sig is greater than 0.05 then there is no autocorrelation.

\section{d. Heteroskedacity Test}

Heteroscedasticity test aims to test whether in the regression model there is an unequal variance from the residuals of one observation to another (Ghozali, 2016). If the variance from one residual to another observation residual is fixed, then it is called homocedasticity. If it is different, it is said that there is heterokedasticity. A good model is that if there is no heterokedastisitas in other words that if there is heterokedastisitas then the model is less efficient.

To detect the presence or absence of heteroscedasticity, the chart method (Scatterplot diagram) is used with the following provisions:

1) If there are certain patterns such as points, which exist to form a regular pattern (wavy, widened, then narrowed), then heteroscedasticity occurs. 
2) If there is a clear pattern and the points spread above and below 0 on the $Y$ axis, then heteroscedasticity does not occur.

\subsection{Multiple Regression Analysis}

In this study, the data analysis method used is multiple regression analysis method. Multiple regression analysis is used to determine whether there is a significant influence between the dependent variable when it is connected with two or more independent variables. In this study, the relationship of net profit margin, debt to equity ratio, and return on equity ratio on company value can be written as a multiple regression equation model as follows:

$$
\mathrm{Y}=\beta_{0}+\beta_{1} \mathrm{X}_{1+} \beta 2 \mathrm{X}_{2}+\beta 3 \mathrm{X}_{3}
$$

dimana:

$\begin{array}{lll}\mathrm{Y} & = & \text { Company Value }(\mathrm{PBV}) \\ \beta_{0} & = & \text { Value Y if } \mathrm{X}=0 \text { or constant value } \\ \beta 1, \beta 2, \beta 3 & = & \text { Regression Coefficient } \\ \mathrm{X}_{1} & = & \text { Net Profit Margin } \\ \mathrm{X}_{2} & = & \text { Debt To Equity Ratio } \\ \mathrm{X} 3 & = & \text { Return On Equity Ratio }\end{array}$

\subsection{Hypothesis Tests}

\section{a. F-Test (Simultaneous Test)}

This test is conducted to determine whether the regression model equation can be used. The F statistical test basically shows whether all the independent variables entered in the model have a simultaneous influence on the dependent variable. The steps in making a decision for the Fad test are:

1) If $F$ count $>F$ table and Sig. value $<A=0.05$ then it can be concluded that simultaneously / together, the independent variables significantly influence the dependent variable.

2) If $\mathrm{F}$ count $<\mathrm{F}$ table and Sig. value $>\mathrm{A}=0.05$, it can be concluded that simultaneously / independent variables do not have a significant effect on the dependent variable.

3) Ho: $b 1=0$, then the net profit margin, debt to equity ratio and return on equity ratio simultaneously / together, have no significant effect on company value / stock price.

4) $\mathrm{Ha}: \mathrm{b} 1 \neq 0$, then the net profit margin, debt to equity ratio and return on equity ratio simultaneously / together, have a significant effect on company value / stock prices.

\section{b. t-test (Partial Test)}

The statistical $\mathrm{t}$ test basically shows how far the influence of one independent variable individually in explaining the variation of the dependent variable (Ghozali, 2016).

The steps in making a decision for the $t$ test are:

1) If $t$ count $>t$ table and Sig. value $<\alpha=0.05$, it can be concluded that partially the independent variable significantly influences the dependent variable.

2) If $t$ count $<t$ table and Sig. value $>\alpha=0.05$, it can be concluded that partially the independent variable has no significant effect on the dependent variable.

3) $\mathrm{H} \mathrm{b}=\mathrm{b}=0$ so the current ratio, debt to equity ratio and return on equity ratio have no significant effect on company value. 
4) $\mathrm{Hb} \neq \mathrm{b} \neq 0$, then the current ratio, debt to equity ratio and return on equity ratio partially have a significant effect on company value.

\section{c. The Coefficient of Determination $\left(\mathbf{R}^{2}\right)$}

The coefficient of determination $\left(\mathrm{R}^{2}\right)$ essentially measures how far the model's ability to explain the variation of independent variables. The value of the coefficient of determination is between zero and one. A small $\mathrm{R}^{2}$ value means that the ability of the independent variables to explain the variation of the dependent variable is very limited. A value close to 1 (one) means that the independent variables provide almost all the information needed to predict the dependent variable and vice versa if near zero does not provide the information needed.

\section{Discussion}

The dependent variable in this study is company value (Price to Book Value). This data is obtained by distributing the value of Book Value per share with the share price. While the Book Value per share is obtained by sharing Total Equity with the number of shares outstanding. The independent variables used are net profit margin, debt to equity and return on equity. Here is the raw data or raw data from each variable.

Table 1. Raw Data Variables

\begin{tabular}{|l|l|l|l|l|l|l|l|}
\hline No & Company & Code & Year & NPM(X1) & DER(X2) & ROE(X3) & PBV(Y) \\
\hline 1 & PT Wilmar & Ceka & 2014 & 0.01 & 1.39 & 0.08 & 0.82 \\
\hline & Cahaya & & 2015 & 0.03 & 1.32 & 0.17 & 0.63 \\
\hline & Kalbar & & 2016 & 0.06 & 0.61 & 0.28 & 0.90 \\
\hline & & & 2017 & 0.03 & 0.54 & 0.12 & 0.85 \\
\hline & & & 2018 & 0.01 & 0.20 & 0.09 & 0.84 \\
\hline 2 & PT Delta & Dlta & 2014 & 0.33 & 0.31 & 0.38 & 8.22 \\
\hline & Djakarta & & 2015 & 0.27 & 0.22 & 0.23 & 4.90 \\
\hline & & & 2016 & 0.33 & 0.18 & 0.25 & 3.96 \\
\hline & & & 2017 & 0.36 & 0.17 & 0.25 & 3.21 \\
\hline & & & 2018 & 0.37 & 0.19 & 0.26 & 3.43 \\
\hline 3 & PT Indofood & Icbp & 2014 & 0.08 & 0.23 & 0.17 & 5.24 \\
\hline & Cbp Sukses & & 2015 & 0.09 & 0.62 & 0.19 & 4.79 \\
\hline & & & 2016 & 0.11 & 0.56 & 0.21 & 5.41 \\
\hline & & & 2017 & 0.10 & 0.56 & 0.18 & 5.11 \\
\hline & & & 2018 & 0.12 & 0.51 & 0.20 & 5.37 \\
\hline 4 & PT Indofood & Indf & 2014 & 0.08 & 0.65 & 0.09 & 1.44 \\
\hline & Sukses & & 2015 & 0.06 & 1.13 & 0.07 & 1.05 \\
\hline & & & 2016 & 0.08 & 0.87 & 0.09 & 1.58 \\
\hline & & & 2017 & 0.07 & 0.88 & 0.09 & 1.43 \\
\hline & & & 2018 & 0.07 & 0.93 & 0.08 & 1.31 \\
\hline 5 & PT Multi & Mlbi & 2014 & 0.27 & 2.01 & 1.44 & 45.47 \\
\hline & Bintang & & 2015 & 0.18 & 1.74 & 0.65 & 22.54 \\
\hline & & & 2016 & 0.30 & 1.77 & 1.20 & 30.17 \\
\hline & & 2017 & 0.39 & 1.36 & 1.24 & 27.06 \\
\hline
\end{tabular}




\begin{tabular}{|l|l|l|l|l|l|l|l|}
\hline No & Company & Code & Year & NPM(X1) & DER(X2) & ROE(X3) & PBV(Y) \\
\hline & & & 2018 & 0.33 & 1.47 & 1.05 & 28.87 \\
\hline 6 & PT Mayora & Myor & 2014 & 0.03 & 1.12 & 0.10 & 4.56 \\
\hline & Indah & & 2015 & 0.08 & 1.18 & 0.24 & 5.25 \\
\hline & & & 2016 & 0.08 & 1.06 & 0.22 & 5.87 \\
\hline & & & 2017 & 0.08 & 1.03 & 0.22 & 6.14 \\
\hline 7 & PT Nippon & Roti & 2014 & 0.10 & 0.87 & 0.20 & 7.30 \\
\hline & Indosari & & 2015 & 0.12 & 1.28 & 0.23 & 5.39 \\
\hline & & & 2016 & 0.11 & 1.02 & 0.19 & 5.61 \\
\hline & & & 2017 & 0.05 & 0.62 & 0.05 & 2.80 \\
\hline & & & 2018 & 0.04 & 0.51 & 0.06 & 2.55 \\
\hline 8 & PT Sekar & Skbm & 2014 & 0.06 & 0.60 & 0.24 & 2.86 \\
\hline & Bumi & & 2015 & 0.03 & 1.22 & 0.12 & 2.57 \\
\hline & & & 2016 & 0.02 & 1.72 & 0.08 & 1.63 \\
\hline & & & 2017 & 0.01 & 0.59 & 0.03 & 1.21 \\
\hline & & & 2018 & 0.02 & 0.70 & 0.01 & 1.15 \\
\hline 9 & PT Siantar & Sttp & 2014 & 0.06 & 0.71 & 0.15 & 4.61 \\
\hline & Top & & 2015 & 0.07 & 0.90 & 0.18 & 3.92 \\
\hline & & & 2016 & 0.07 & 1.00 & 0.15 & 3.58 \\
\hline & & & 2017 & 0.08 & 0.69 & 0.16 & 4.12 \\
\hline & & & 2018 & 0.10 & 0.60 & 0.15 & 2.98 \\
\hline 10 & PT Ultra & Ultj & 2014 & 0.07 & 0.01 & 0.13 & 4.74 \\
\hline & Milk & & 2015 & 0.12 & 0.27 & 0.19 & 4.07 \\
\hline & & & 2016 & 0.15 & 0.21 & 0.20 & 3.78 \\
\hline & & 2017 & 0.15 & 0.23 & 0.17 & 3.55 \\
\hline & & 2018 & 0.14 & 0.16 & 0.15 & 3.27 \\
\hline
\end{tabular}

The variables in this study are described using descriptive statistics. The variables used in descriptive statistical analysis are net profit margin, debt to equity, return on equity, and price to book value. Descriptive statistical analysis is shown in Table 2 below:

Table 2. Descriptive Statistics

\begin{tabular}{cc|c|c|c|c} 
& $\mathrm{N}$ & Minimum & Maximum & Mean & Std. Deviation \\
\hline NPM & 50 & .01 & .39 & .1208 & .10608 \\
\hline DER & 50 & .01 & 2.01 & .7956 & .48715 \\
\hline ROE & 50 & .01 & 1.44 & .2576 & .30939 \\
\hline PBV & 50 & .63 & 45.47 & 6.2994 & 8.82014 \\
\hline
\end{tabular}

Valid N (listwise) $\quad 50$

Based on Table 2, it can be seen that $\mathrm{N}$ or the total amount of data for each variable is 50 over the 2014-2018 period. The average value of net profit margin in this study was 0.128 times. The average value of debt to equity ratio in this study is 0.7956 times. The average value of return on equity in this study was 0.2576 times. The average price to book value in this study was 6.2994 times.

The independent variable Net profit margin in this study was 0.128 times. The average value of debt to equity ratio in this study was 0.7956 times. The average value of return on 
equity in this study was 0.2576 times. The average price to book value in this study was 6.2994 times.

The independent variable Net Profit Margin Ratio, has a value of std. deviation of 0.14106, the minimum value of 0.01 was obtained by PT Cahaya Kalbar in 2014 and 2018, while the maximum value of 0.39 was obtained by PT Multi Bintang Indonesia in 2017.

The variable independent Debt to Equity Ratio, has a std. Deviation value of 0.29378, a minimum value of 0.01 was obtained by PT Ultra Jaya Milk in 2014. In the lowest DER industry, PT UltraJaya and PT Delta Jakarta were obtained. A maximum value of 2.01 was obtained by PT Multi Bintang in 2014 and in the high DER industry successively it was obtained by PT Multi Bintang, followed by PT Sekar Bumi, PT Wilmar Cahaya Kalbar and PT Mayora.

The variable independent Return on Equity Ratio, has a std Deviation value of 0.22568 , a minimum value of 0.01 obtained by PT Sekar Bumi in 2018, in the low Return on Equity industry the average is held by PT Sekar Bumi and PT Nippon Sari Roti. A maximum value of 1.44 was obtained by PT Multi Bintang in 2014 and in the industries of PT Multi Bintang, PR Delta Jakarta and PT Mayora the sequences were quite high.

The variable dependent Price to Book Ratio, has a std. Deviation value of 1.25919 , a minimum value of 0.63 obtained by PT Cahaya Kalbar in 2015. In industry, a company with a fairly low PBV is PT Cahaya Kalbar (range 0.8-0.9), PT Indofood Sukses Makmur (range 1- 1.9) and PT Sekar Bumi (range 1.15 to 2.86) obtained a maximum value of 45.47 obtained by PT Multi Bintang in 2014. In the highest PBV industry in a row from PT Multi Bintang (22.54 to 45.47), PT Mayora (range 5.25 - 6.86), and PT Indofood CBP (range 4.79 to 5.41)

The normality test aims to see whether in the regression model, confounding variables have a normal distribution. The initial normality test can be seen from the one-sample Kolmogorov-Smirnov Test table and the normal probability plot shown below.

Table 3. Normality Test Results before transformation

One-Sample Kolmogorov-Smirnov Test

\begin{tabular}{|ll|l|}
\hline & & \multicolumn{1}{|c|}{ Unstandardized Residual } \\
\hline $\mathbf{N}$ & & 50 \\
\hline Normal Parameters ${ }^{\mathrm{a}, \mathrm{b}}$ & Mean & .0000000 \\
\cline { 2 - 3 } & Std. Deviation & 2.07154579 \\
\hline Most Extreme Differences & Absolute & .162 \\
\cline { 2 - 3 } & Positive & .108 \\
\cline { 2 - 3 } & Negative & -.162 \\
\hline Test Statistic & & .162 \\
\hline Asymp. Sig. (2-tailed) & & $.002^{\mathrm{c}}$ \\
\hline
\end{tabular}

Data Sources are processed with SPSS 24.0

From the results of table 3 above, it can be seen that one-sample Kolmogorov-Smirnov table shows that the data are not normally distributed, because of the Asymp. Sig. value (2 tailed) obtained from NPM, DER, DER and PBV are 0.002, where the value of 0.002 is smaller than $\alpha=0.05$ indicating the results of data are not normally distributed. 


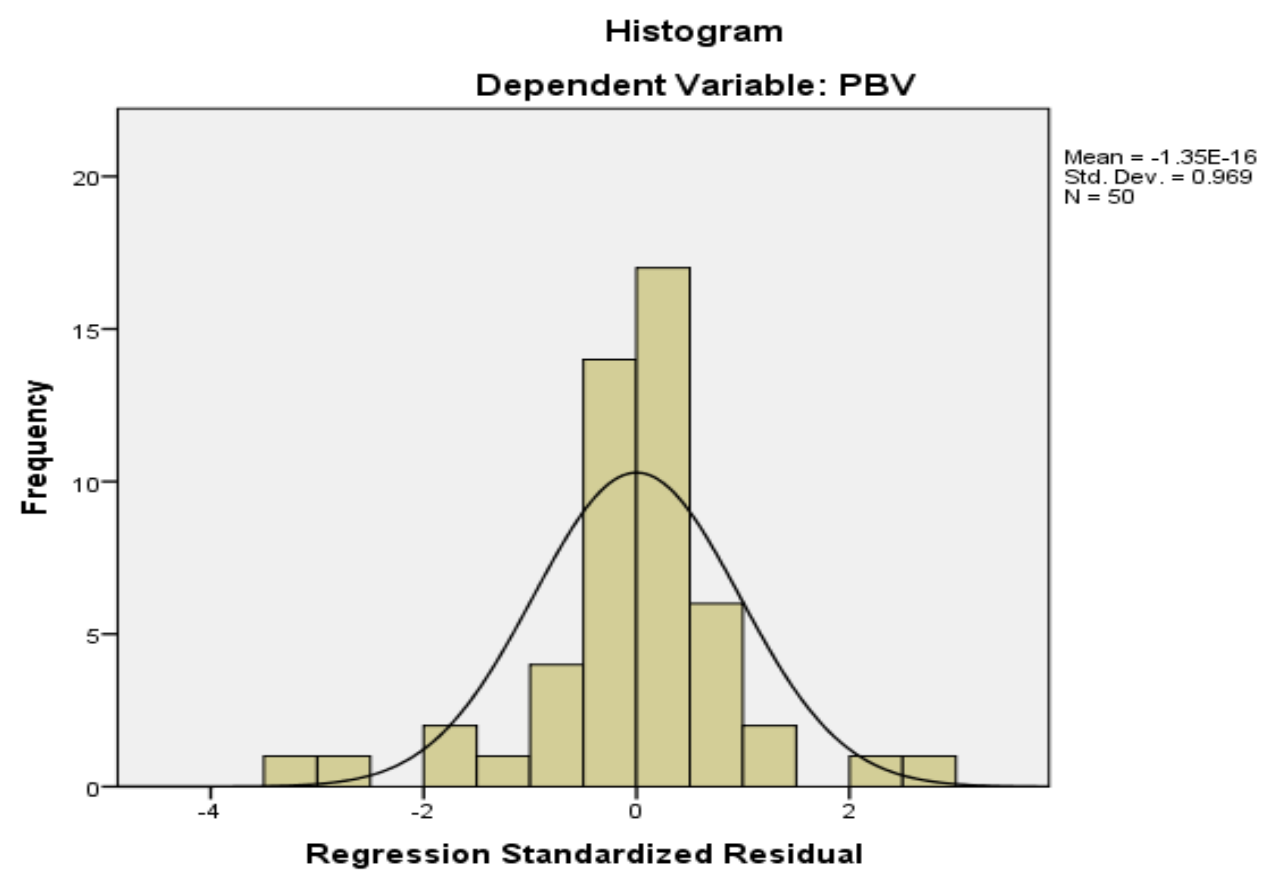

Figure 2. Probability Histogram

Data Sources are processed with SPSS 24.0

From the figure 2 above it can be seen that the data has always been left and right, indicating that the data is not normally distributed.

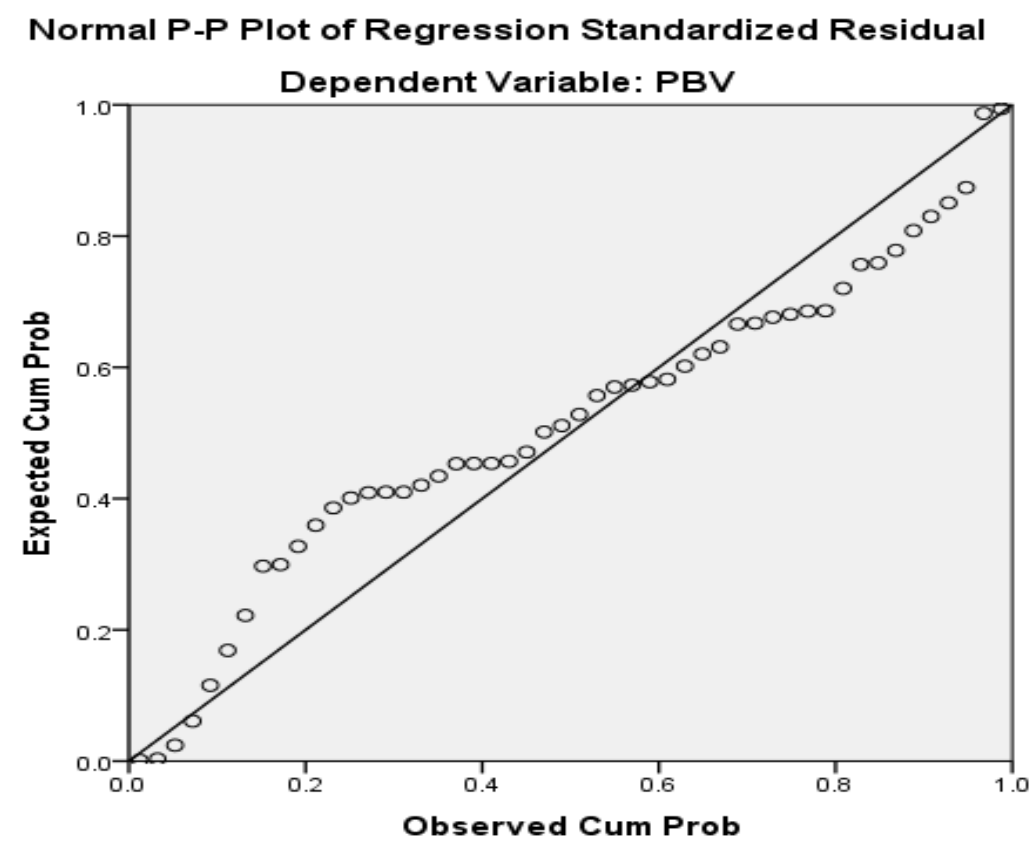

Figure 3. Normal Probability Plot Graphs Before Transformation Data Sources are processed with SPSS 24.0

From Figure 3 you can see that the points are moving away from the diagonal line. This shows that the data is not normally distributed. 
Table 4. Multicollinearity Test Results before transformation

\section{Coefficients $^{\mathrm{a}}$}

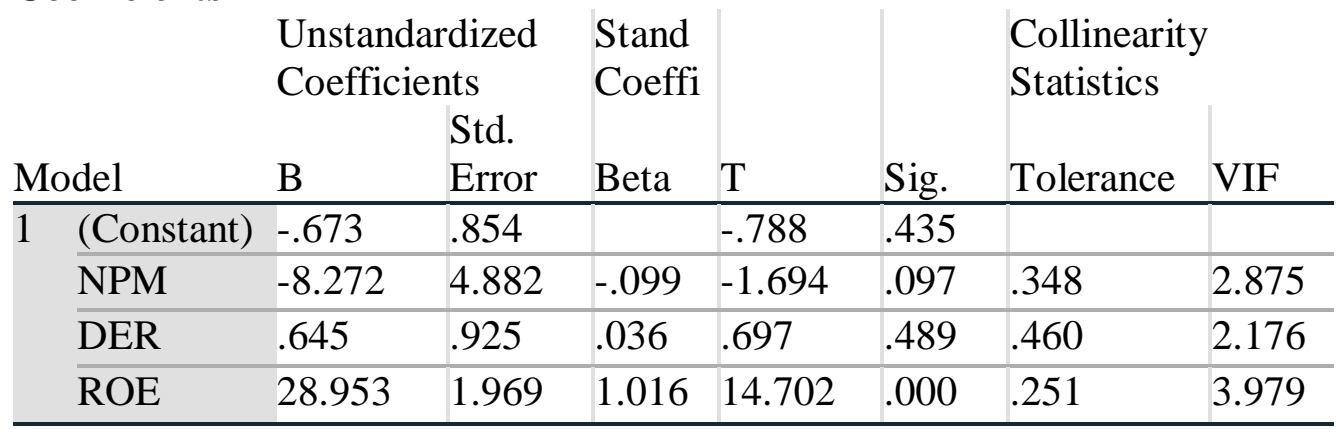

The data source is processed with SPSS 24.0

The tolerance numbers are $0.348,0.460,0.251$ and all are $>0.1$ and the VIF numbers are $2.875,2.176,3.979$ where all of them are $<10$. These tolerance numbers indicate passing multicollinearity tests and there is no multicollinearity between independent variables in the regression model.

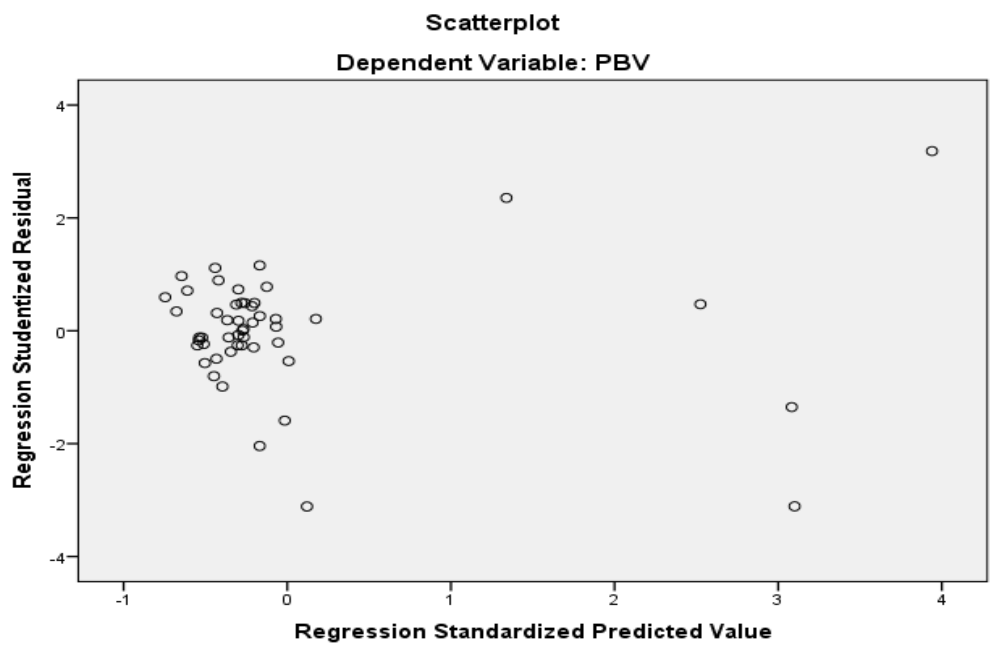

Figure 4. Normal Probability Plot Graphs before Transformation Data Sources are processed with SPSS 24.0

Based on the figure above, scatterplots graph after transformation shows that the points accumulate to the left of the graph, not spread either above or below the number 0 on the $\mathrm{Y}$ axis. It can be concluded that there is heteroscedasticity in the regression model.

Table 5. Autocorrelation Test Results before Transformation

\begin{tabular}{lll}
\multicolumn{2}{l}{ One-Sample Kolmogorov-Smirnov Test } & Unstandardized Residual \\
\hline $\mathrm{N}$ & & 50 \\
\hline Normal Parameters & & \\
& Mean & .0000000 \\
\cline { 2 - 3 } Most Extreme Differences & Std. Deviation & 2.07154579 \\
& Absolute & .162 \\
\cline { 2 - 3 } & Positive & .108 \\
\cline { 2 - 3 } & Negative & -.162 \\
\hline Test Statistic & & .162 \\
\hline
\end{tabular}




Asymp. Sig. (2-tailed) $\quad .002^{\mathrm{c}}$

a. Test distribution is Normal.

b. Calculated from data.

c. Lilliefors Significance Correction.

The results of this test give a significant Asymp. result of 0.2. This number is greater than 0.05 , meaning that the data is normally distributed. If Asymp. Sig. (2-tailed) $\geq 0.05$, the regression model produces normally distributed values.

Table 6. Results of Normality Test after Transformation

Kolmogorov-Smirnov Test

\section{One-Sample}

Unstandardized Residual

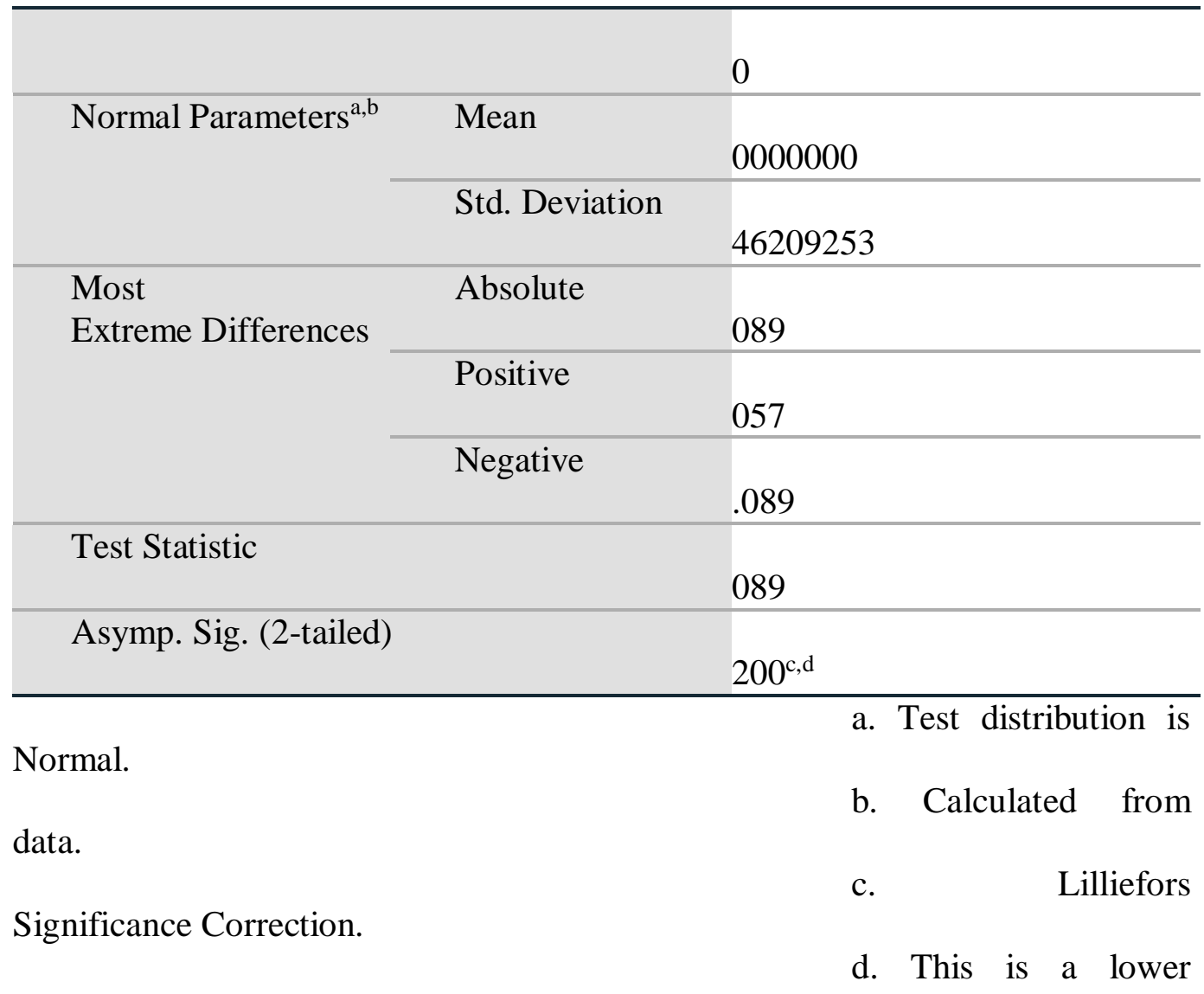

bound of the true significance.

Data Sources are processed with SPSS 24.0 


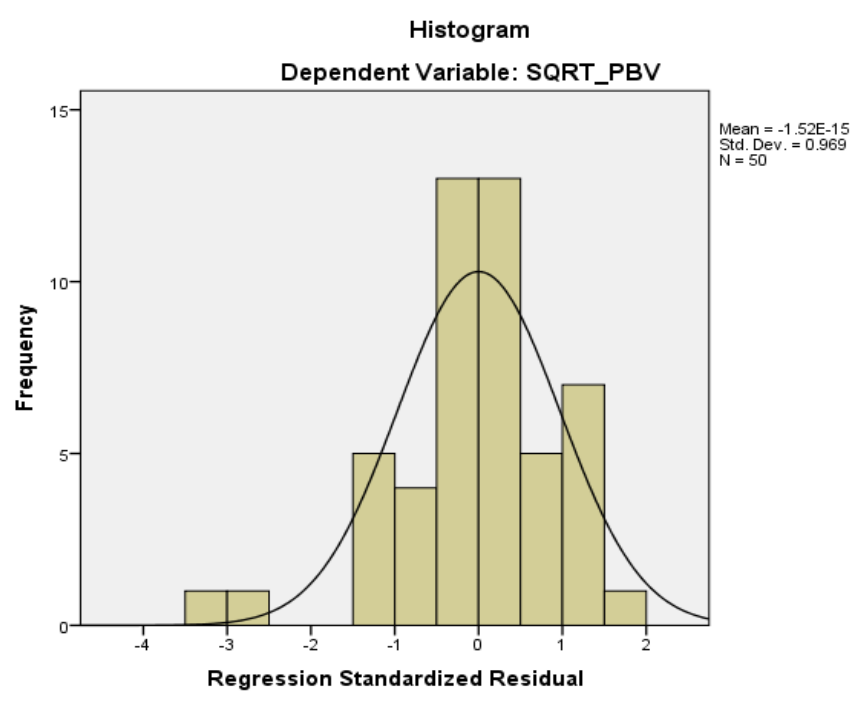

Figure 5. Histogram Graph after Transformation

Data Source is processed in 2019 with SPSS 24.0

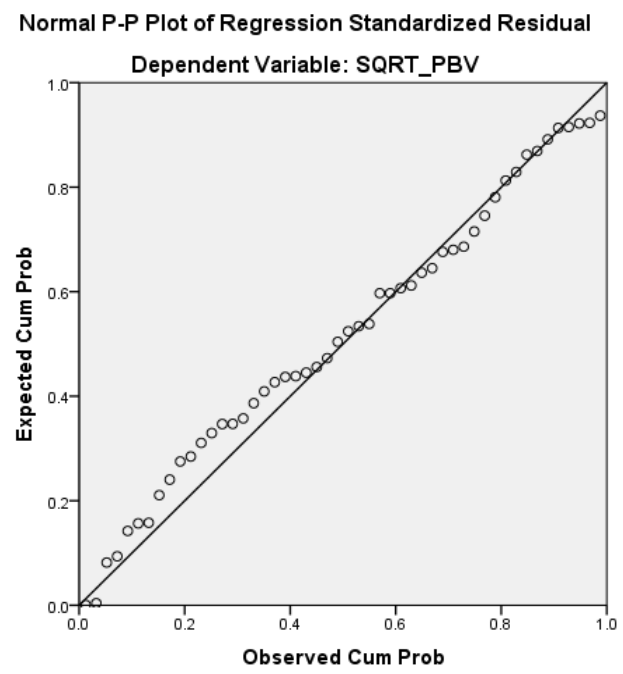

Figure 6. Normal Probability Plot Graph after Transformation Data Sources are processed with SPSS 24.0

Multicollinearity test aims to test whether the regression model found a correlation between independent variables.

Tabel 7. Multicollinearity Test Results after Transformation

\section{Coefficients $^{\mathrm{a}}$}

\begin{tabular}{|c|c|c|c|c|c|c|c|}
\hline \multirow[b]{2}{*}{ Model } & \multicolumn{2}{|c|}{$\begin{array}{l}\text { Unstandardized } \\
\text { Coefficients }\end{array}$} & \multirow{2}{*}{$\begin{array}{l}\text { Standardized } \\
\text { Coefficients } \\
\text { Beta }\end{array}$} & \multirow[b]{2}{*}{$\mathrm{t}$} & \multirow[b]{2}{*}{ Sig. } & \multicolumn{2}{|c|}{$\begin{array}{l}\text { Collinearity } \\
\text { Statistics }\end{array}$} \\
\hline & B & Std. Error & & & & Tolerance & VIF \\
\hline \begin{tabular}{|l|l|}
1 & (Constant)
\end{tabular} & -.400 & .311 & & -1.286 & .205 & & \\
\hline SQRT_NPM & .072 & 904 & .008 & .080 & .937 & .285 & 3.504 \\
\hline SQRT_DER & .340 & 318 & .079 & 1.070 & .290 & .533 & 1.878 \\
\hline
\end{tabular}




\begin{tabular}{|l|l|l|l|l|l|l|l|} 
SQRT_ROE & 4.979 & .604 & .892 & 8.246 & .000 & .250 & 4.000 \\
\hline
\end{tabular}

Dependent Variable: SQRT_PBV

Data Sources are processed with SPSS 24.0

The tolerance numbers are $0.285,0.533,0.250$ where all are $>0.1$ and the VIF number is $3.504,1.8878,4,000$ where all are $<10$. These tolerance numbers indicate that this test passes the multicollinearity test because there is no multicollinearity between independent variables in the regression model.

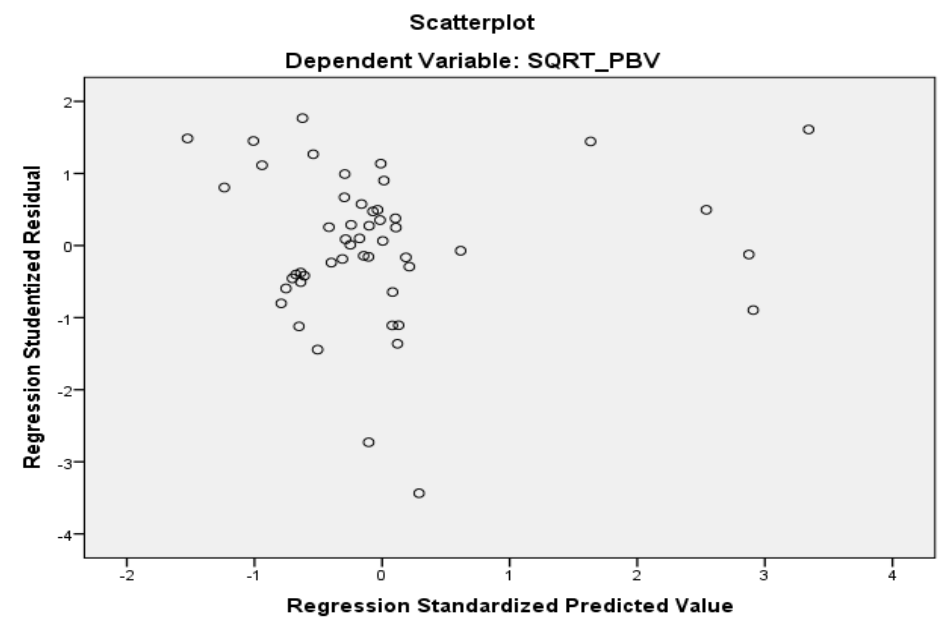

Figure 7. Scatterplot Graph after Transformation

Data Sources are processed with SPSS 24.0

Based on the figure above, scatterplots graph after transformation shows that the points spread randomly and spread both above and below the number 0 on the $\mathrm{Y}$ axis. It can be concluded that there is no heteroscedasticity in the regression model.

\section{Runs Test}

Table 8. Autocorrelation Test Results

\begin{tabular}{|l|l|}
\hline & Unstandardized Residual \\
\hline Test Value & a \\
\hline Cases $<$ Test Value & .01702 \\
\hline Cases $>=$ Test Value & 25 \\
\hline Total Cases & 25 \\
\hline Number of Runs & 50 \\
\hline Z & 20 \\
\hline Asymp. Sig. (2-tailed) & -1.715 \\
\hline
\end{tabular}

Data Sources are processed with SPSS 24.0

Once again a run test was performed and the Asymp sig result was 0.086, already> 0.05 , indicating the data passed the autocorrelation test.

Based on the SPSS output, we obtain the data to be used for the analysis of multiple linear regression equations as follows: 
Table 9. Analysis of Multiple Linear Regression Equations

\section{Coefficients $^{\mathrm{a}}$}

\begin{tabular}{|c|c|c|c|c|c|c|c|c|}
\hline \multirow{2}{*}{\multicolumn{2}{|c|}{ Model }} & \multicolumn{2}{|c|}{$\begin{array}{l}\text { Unstandardized } \\
\text { Coefficients }\end{array}$} & \multirow{2}{*}{$\begin{array}{l}\text { Standardized } \\
\text { Coefficients } \\
\text { Beta }\end{array}$} & \multirow[t]{2}{*}{$\mathrm{t}$} & \multirow[t]{2}{*}{ Sig. } & \multicolumn{2}{|c|}{ Collinearity Statistics } \\
\hline & & $\mathrm{B}$ & Std. Error & & & & Tolerance & VIF \\
\hline & (Constant) & -.400 & .311 & & -1.286 & .205 & & \\
\hline & SQRT_NPM & .072 & .904 & .008 & .080 & .937 & 285 & 3.504 \\
\hline & SQRT_DER & .340 & .318 & .079 & 1.070 & .290 & .533 & 1.878 \\
\hline & SQRT_ROE & 4.979 & .604 & .892 & 8.246 & .000 & 250 & 4.000 \\
\hline
\end{tabular}

Dependent Variable: SQRT_PBV

Source of processed data from SPSS 24.0

The Regression equation of influence between independent and dependent variables in this study can be written as follows: $Y=\beta_{0}+\beta_{1} X_{1+} \beta 2 X_{2}+\beta 3 X_{3}$

$\begin{array}{ll}Y & \text { Company Value }(\mathrm{PBV}) \\ \beta_{0} & \text { Value } \mathrm{Y} \text { if } \mathrm{X}=0 \text { or constants value } \\ \beta 1, \beta 2, \beta 3 & \text { Regression Coefficient } \\ \mathrm{X}_{1} & \text { Net Profit Margin Ratio } \\ \mathrm{X}_{2} & \text { Debt To Equity Ratio } \\ \mathrm{X} 3 & \text { Return On Equity Ratio }\end{array}$

Company Value $(\mathrm{Y})=-0,400+0.072 \mathrm{NPM}+0.340 \mathrm{DER}+4,979 \mathrm{ROE}$

\section{Coefficients $^{\mathrm{a}}$}

Table 10. Test Results - $\mathrm{t}(\mathrm{t}$ - Test)

\begin{tabular}{|c|c|c|c|c|c|c|c|c|}
\hline \multirow{2}{*}{\multicolumn{2}{|c|}{ Model }} & \multicolumn{2}{|c|}{$\begin{array}{l}\text { Unstandardized } \\
\text { Coefficients }\end{array}$} & \multirow{2}{*}{$\begin{array}{l}\text { Standardized } \\
\text { Coefficients } \\
\text { Beta }\end{array}$} & \multirow[b]{2}{*}{$\mathrm{t}$} & \multirow[b]{2}{*}{ Sig. } & \multicolumn{2}{|c|}{$\begin{array}{l}\text { Collinearity } \\
\text { Statistics }\end{array}$} \\
\hline & & $\mathrm{B}$ & Std. Error & & & & Tolerance & VIF \\
\hline 1 & (Constant) & -.400 & .311 & & -1.286 & .205 & & \\
\hline & SQRT_NPM & .072 & .904 & .008 & .080 & 937 & 285 & 3.504 \\
\hline & SQRT_DER & .340 & .318 & .079 & 1.070 & 290 & .533 & 1.878 \\
\hline & SQRT_ROE & 4.979 & .604 & .892 & 8.246 & .000 & 250 & 4.000 \\
\hline
\end{tabular}

Dependent Variable: SQRT_PBV

Source of processed data from SPSS 24.0

From the $t$ test results obtained table regression equation as above where it is known that $\mathrm{t}$ table is $=2.0086$.

The requirement for a relationship between the independent variables and the dependent variable is that $\mathrm{t}$ table $<\mathrm{t}$ counts in the calculation table above;

1) t count NPM: $0.080<2.0086$ (not related and not significant), means that NPM has no effect and is not significant to the company value, means that $\mathrm{H} 1$ is accepted

2) t count DER: $1,070<2.0086$ (not related and not significant), means that DER has no effect and on the company value, means that $\mathrm{H} 2$ is accepted

3) t count ROE: 8,246> 2,0086 (related and significant) means that DER has no effect and is not significant on company value, means that $\mathrm{H} 3$ is accepted 
Based on the results of the SPSS output it appears that the effect of simultaneously 3 independent variables (NPM, DER, and ROE) on the dependent variable (PBV) can be shown as in the following table.

Table 11. Test Results F

ANOVA ${ }^{\mathrm{a}}$

\begin{tabular}{|l|l|l|l|l|l|l|}
\hline \multicolumn{2}{|l|}{ Model } & Sum of Squares & df & Mean Square & F & Sig. \\
\hline \multirow{4}{*}{1} & Regression & 67.230 & 3 & 22.410 & 98.525 & $.000^{\mathrm{b}}$ \\
\cline { 2 - 8 } & Residual & 10.463 & 46 & .227 & & \\
\cline { 2 - 8 } & Total & 77.693 & 49 & & & \\
\hline
\end{tabular}

Dependent Variable: SQRT_PBV

Source: Data processed in 2019 with SPSS 24.0

Seen from the results of test the above data obtained a significant value of 0,000 . Significant value is smaller than $5 \%$ which can be concluded that the independent variable net profit margin, debt to equity ratio, return on equity together (simultaneously) affect the company value.

Also, the F-count results in the above test data (98.525) are greater than the F-table (2.79) so that it can be concluded that the net profit margin, debt to equity ratio, return on equity together (simultaneously) have a significant effect on the company value.

Table 12. Coefficient of Determination

Model Summary ${ }^{b}$

\begin{tabular}{|l|l|l|l|l|l|}
\hline Model & $\mathrm{R}$ & $\mathrm{R}$ Square & Adjusted R Square & Std. Error of the Estimate & Durbin-Watson \\
\hline 1 & $.930^{\mathrm{a}}$ & .865 & .857 & .47692 & .930 \\
\hline
\end{tabular}

Predictors: (Constant), SQRT_ROE, SQRT_DER, SQRT_NPM

The meaning of the determination coefficient test table is that NPM, DER, ROE variables can explain the company value at $85.7 \%$. The remaining $14.3 \%$ was explained by other variables outside the study. The coefficient of determination test is used to test the goodness fit of the regression model. The number of 85.7 percent is close to 100 percent, means that the correlation between independent and dependent variables is very close.

The results of the study of the debt to equity ratio variable indicate that this variable has no effect on the company value and shows that the debt to equity ratio does not have an important role in increasing the company value. This means investors in making investment decisions are not based on DER indicators.

The company in determining its capital structure is not fully financed with debt. Even with the debt, the company will get savings on taxes, but the use of debt that is too large will burden the company's net profit in the case of paying a large interest expense. As far as greater benefits, additional debt is still permitted, but if the sacrifice due to the use of debt is already greater, then additional debt is not permitted. DER has no effect on company value. The size of the debt owned by the company is not given much attention by investors, because investors look more at how the company's management uses these effectively and efficiently to achieve added value to the company's value. This happens due to the fact that investors see that the debt incurred by the company can have a high or increasing cost of fund which will have an impact on the decline in corporate profits which will impact on the returns to investors. 
The results of this study is in line with the results of research by Alfredo Mahendra (2015), Alif Wahyu Wicaksana (2018) and Imam Ramantio's research (2018) namely that the debt to equity ratio has no effect on the company value in manufacturing companies listed on the IDX. But the results of this study not supported by the research of Dzulfikar Dwi Wahyu (2018) which states that DER influences the calculation of company value.

The results of the F Test and the coefficient of determination test illustrate that Net Profit Margin, Debt To Equity Ratio, and Return On Equity not only have a simultaneous effect on company value but also have a very large correlation, which is 85.7 percent in effecting company valuation.

\section{Conclusion}

Partially, Net Profit Margin has no effect on the company value in food and beverage companies on the Indonesia Stock Exchange in 2014-2018. Partially, Debt to Equity has no effect on the company value in food and beverage companies on the Indonesia Stock Exchange in 2014-2018. Partially, Return on Equity affects the company value in food and beverage companies on the Indonesia Stock Exchange in 2014-2018. Net Profit Margin, debt to equity ratio, return on equity simultaneously have a significant effect on company value in food and beverage companies on the Indonesia Stock Exchange in 2014-2018.

\section{References}

Agus, R. Sartono. (2010). Manajemen Keuangan Teori dan Aplikasi Pendekatan Matematis, Edisi Keempat. Jakarta: PT. Gramedia Pustaka Umum.

Awat, Napa J. (1999). Manajemen Keuangan Pendekatan Matematis J, Edisi Kedelapan. Jakarta: PT. Gramedia Pustaka Umum.

Bursa Efek Indonesia. (2019). Laporan Keuangan dan Tahunanan 2012-2017. (Online). www.idx.co.id

Fahmi. Irham. (2014). Pengantar Management Keuangan. Bandung: Alfabeta.

Ghozali, Imam. (2013). Aplikasi Analisis Multivariate dengan Program. Semarang: Badan Penerbit Universitas Diponegoro.

Martono and Harijito. (2003). Manajement Keuangan. Yogyakarta: Ekonisa.

Subiyantoro, Edi and Fransisca Andreni. (2003). Anlisis Faktor-faktor yang Mempengaruhi Harga Sham. Journal Manajement dan Kewirausahaan Vol.5 No. 2 Septembet 2003. 171-180

Sugiyono. (2012). Metode Penelitian Bisnis. Bandung: Alfabeta.

Suwardjono. (2010). Teori Akuntasi Perekayasaan Laporan Keuangan. Edisi Ketiga. Yogyakarta: BPFE 